\title{
Ecological and Agrotechnical Aspects of Cultivation of Salvia Sclarea L. Under Conditions of Drip Irrigation in the South of Ukraine
}

\author{
Victor Chaban'1, Victor Ushkarenko ${ }^{2}$, Olena Markovska², Volodymyr Dudchenko ${ }^{3}$ \\ 1 Kherson State Maritime Academy, Ushakova St. 20, 73009, Kherson, Ukraine \\ 2 Kherson State Agrarian and Economic University, Stritenska St. 23, 73006, Kherson, Ukraine \\ 3 Institute of Rice of NAAS, Studentska Street 11, Antonivka, Skadovsk district Kherson region, 75705, Ukraine \\ * Corresponding author's e-mail: mark.elena@ukr.net
}

\begin{abstract}
Salvia sclarea L. is a commercially important crop from the Lamiaceae family, the raw material of which serves as a source of valuable essential oil. Effects of fertilizers, ploughing depth, time of sowing and row spacing on the productivity of nutmeg sage grown under conditions of drip irrigation were investigated in the field experiments conducted on meadow-chestnut residual-saline medium-loam soils of the southern Ukraine. It was found that time of sowing and fertilizer dose had a greater impact on the productivity of sage than row spacing and ploughing depth. Regarding the duration of $S$. sclarea L. cultivation, it was determined that within the first three years the inflorescence yield ranged from $9.98-10.62 \mathrm{t} / \mathrm{ha}$, and in the fourth year - decreased by 6.8 times, amounting to $0.74-1.74 \mathrm{t} / \mathrm{ha}$. The maximum productivity of the plant was achieved in the second year of cultivation during the winter sowing period with row spacing of $45 \mathrm{~cm}$, ploughing depth of $28-30 \mathrm{~cm}$ and dose of $\mathrm{N}_{60} \mathrm{P}_{90}$ fertilizer of $15.01 \mathrm{t} / \mathrm{ha}$. With the same ploughing depth and dose of $\mathrm{N}_{60} \mathrm{P}_{90}$ fertilizer, high level of productivity, $14.74 \mathrm{t} / \mathrm{ha}$, was also achieved when row spacing of $70 \mathrm{~cm}$ was used. Application of mineral fertilizers at doses similar to $\mathrm{N}_{60} \mathrm{P}_{90}$ under the main tillage during winter sowing period resulted in $51.1 \mathrm{~kg} / \mathrm{ha}$ and $51.3 \mathrm{~kg} / \mathrm{ha}$ yields of essential oil in the first and second years of cultivation, respectively. In the third and fourth years, the yields dropped to $33.3 \mathrm{~kg} / \mathrm{ha}$ and $8.7 \mathrm{~kg} / \mathrm{ha}$ or by $35.1 \%$ and $83.0 \%$, respectively. During spring sowing period, the yield of essential oil was in the range of $19.2-24.6 \mathrm{~kg} / \mathrm{ha}$ in the first three years, but in the fourth year - decreased to $6.5 \mathrm{~kg} / \mathrm{ha}$ or by $73.6 \%$. Therefore, to obtain inflorescence yield of nutmeg sage at the level of 14.5-15.0 t/ha with essential oil yield of $51.0 \mathrm{~kg} / \mathrm{ha}$ in arid climates, it is recommended to use drip irrigation, row spacing of $45 \mathrm{~cm}$, ploughing depth of 28-30 cm, fertilizer at a dose of $\mathrm{N}_{60} \mathrm{P}_{90}$ and sowing time in the first ten-day period of December (winter period).
\end{abstract}

Keywords: sowing time, ploughing, fertilizer, row spacing, yield.

\section{INTRODUCTION}

Declining margins in cultivation of grain, oilyielding and some industrial crops on the global and Ukrainian agricultural markets make agricultural producers look for non-traditional, uncommon and at the same time, highly profitable crops, such as essential oil and medicinal plants. The growing interest of farmers and scientists in these promising crops can also be attributed to drought and heat resistance - properties that are relevant under conditions of gradual global warming, which is accompanied by reduced rainfall, lower humidity, higher temperature and solar radiation intensity, more frequent dry winds, increased numbers of pests and plant pathogens, etc. Another important factor is the global trend of environmentally friendly cultivation of plants, which serve as a raw material for pharmaceutical, food, perfume and cosmetic industries. With global production of essential oils constantly increasing and currently reaching 250 thousand tons per year, there are about 300 niche essential oil plants, the cultivation of which has a strong economic impact [Mirzoeva, 2019]. In contrast to artificially synthesized oils, natural essential oils are comprised of a variety of different compounds, including aromatic compounds, organic 
acids, phenols, alcohols and aldehydes, which are responsible for their high price. Of particular interest are crops, the oils of which can be used for different purposes, e. g. coriander, mint, lemon balm, fennel, monarda, sage, which yield spicyaromatic, medicinal and essential oils [Makukha et al., 2018; Olkhovich and Fedko, 2019; Dudchenko et al., 2020; Markovska et al., 2020]. However, the cultivation of these plants bears certain risks associated with the need for constant monitoring of domestic and foreign markets or lack of agricultural knowledge and technical capabilities in enterprises [Mirzoeva, 2019]. Having analyzed the available literature on the methodology of growing essential oil and medicinal plants, we concluded that most modern experiments focus on the creation of high-yielding varieties and hybrids, the possibility of their introduction in different soil and climatic zones, study of morphological and biological features of plants, reproduction of seedlings, determination of the amount and composition of essential oils [Nasermoadeli and Rowshan, 2013; Svydenko and Yezhov, 2015; Mamadalieva et al., 2017; Grigoriadou et al., 2020]. Yet, agricultural techniques for their cultivation, especially given the conditions created by the gradual warming of the planet, are not well characterized [Tuttolomondo et al., 2020]. Since soil and climatic conditions of the southern Ukraine are favorable for growth and development of essential oil crops, it is vital to improve the existing and develop new technological methods for their cultivation in order to obtain high quality, environmentally friendly raw plant materials.
Salvia sclarea L. is a commercially important crop from the Lamiaceae family, the raw material of which serves as a source of valuable essential oil (Fig. 1). Due to its broad range of properties, oil of nutmeg sage is widely used. For instance, in the pharmaceutical industry it used as an antimicrobial; in the food industry - to manufacture alcoholic beverages and confectionery with a characteristic nutmeg aroma; in the tobacco industry - to aromatize expensive varieties of tobacco. The waste produced during the distillation of the essential oil contains a significant amount of sclareol, which can be used for synthesis of substances with the scent of ambergris. Drying oil is used to make high quality drying oil. In addition, oil of nutmeg sage is an aphrodisiac. Leaves, fresh and dry inflorescences are used as a seasoning for culinary products, enhancing the aroma of cheese, sausages, tea and other products. In some countries, sage flowers are used to make a fragrant alcoholic drink. In Mexico and Chile, soft drinks are made from roots and young stems, while the above-ground part of the plant is added to beer and wine, which gives them a nutmeg taste and smell [Farka et al., 2005; Sharopov and Setzer, 2012].

S. sclarea L. was first grown in France in 1909, while in Ukraine it has been cultivated since 1929. The main regions of cultivation are located in the AR Crimea, Zaporizhya and Kherson regions. Even during severe droughts, the plant can still generate high inflorescence yields. The average yield of nutmeg sage inflorescence in Ukraine is 3.5-4.0 t/ha but yields ranging from 3.0 to 8.5 t/ha are also reported. The average yield

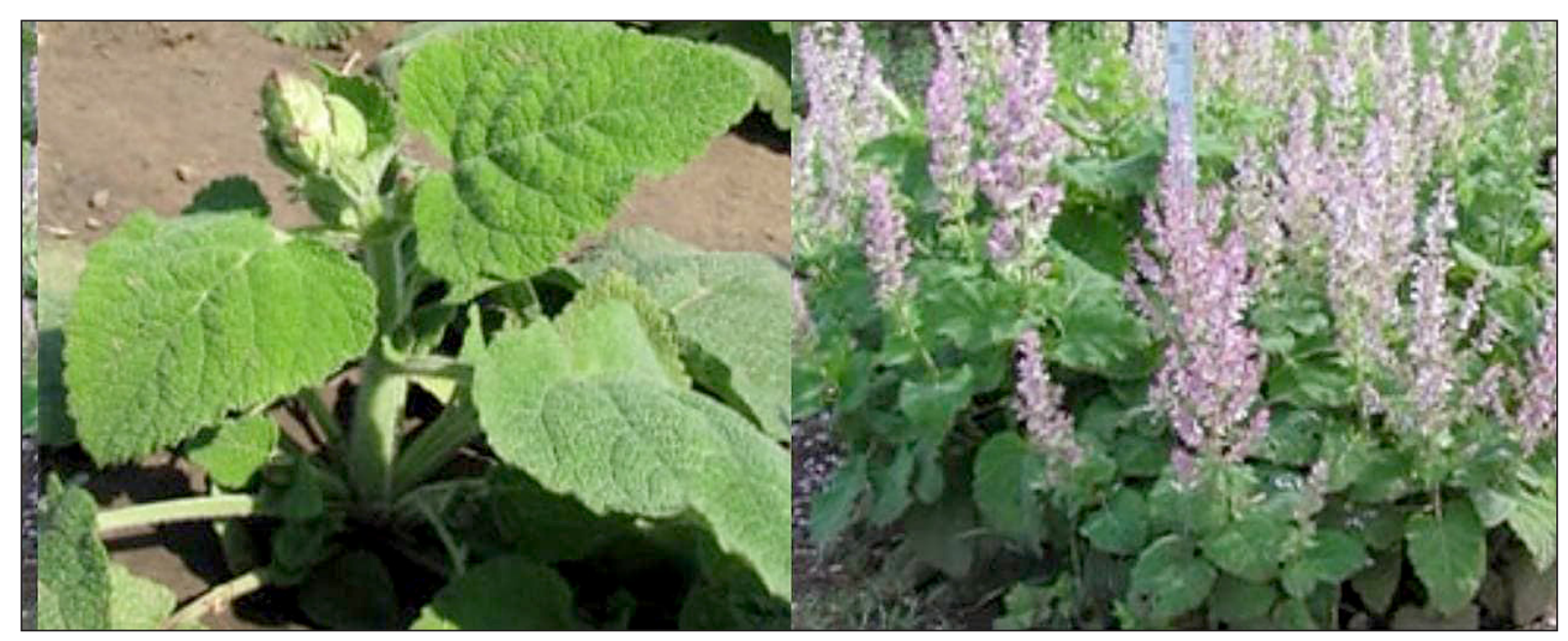

Figure 1. General appearance of the plant S. sclarea L. 
of essential oil is $15-23 \mathrm{~kg} / \mathrm{ha}$ [Rabotyagov et al., 2011; Chaban and Ushkarenko, 2020]. Rabotyagov and Svydenko [2003] studied morphological, biological and biochemical properties of sage as well as its productivity depending on the time of sowing in Kherson region. For the foreststeppe conditions of Ukraine, Yurchak [1997] recommended and implemented a technology for growing leading aromatic crops, including S. sclarea L. To determine the optimal plant density and weed control methods under conditions drip irrigation, field studies were conducted in Italy at Scuola Agraria Salesiana of Lombriasco (4450'35.15”N; 7³8'17.36”'E, 254 ma.sl) [Tibaldi et al, 2010]. The influence of growing conditions on the composition of S. sclarea L. essential oil in the conditions of Southern Uzbekistan was not confirmed [Dzumayev et al., 1995]. Therefore, limited information on the technological aspects of growing nutmeg sage in arid climates determined the relevance of this study.

\section{MATERIALS AND METHODS}

Effects of fertilizers, ploughing depth, time of sowing and row spacing on the productivity of nutmeg sage were investigated in the field experiments conducted on meadow-chestnut residualsaline medium-loam soils of "Agrofirm-Dodola" in Beryslav district of Kherson region in 20112018. The climate of Kherson region is temperate continental with mild winters (average temperatures of winter months $\left.(-1)-(-3)^{\circ} \mathrm{C}\right)$, hot and long summers (average temperatures $22-23{ }^{\circ} \mathrm{C}$, maximum - more than $40^{\circ} \mathrm{C}$ ). The average annual air temperature is $9.3-9.8^{\circ} \mathrm{C}$. The average annual precipitation in the region is about $400 \mathrm{~mm}$, but the amount of precipitation has increased over the last decade. The north-western areas have the largest amount of precipitation $(450-470 \mathrm{~mm})$, while the southern areas - the smallest $(300 \mathrm{~mm})$. The predominant amount of precipitation occurs in summer, in the form of showers. In winter, the snow cover is unstable and in recent years - almost absent. Weather conditions were favorable for plant growth and development in 2016-2018. In 2011-2013, most precipitation occurred during winter and droughts were observed in spring, which negatively affected the initial growth of $S$. sclarea L., especially in the acutely arid 2012.
The experiments included the following factors and their variants: Factor A - crop fertilization: without fertilizers (control), $\mathrm{N}_{60} \mathrm{P}_{30}, \mathrm{~N}_{60} \mathrm{P}_{60}$, $\mathrm{N}_{60} \mathrm{P}_{90}$; Factor $\mathrm{B}$ - ploughing depth: $20-22 \mathrm{~cm}$, 28-30 cm; Factor C - sowing time: the first (first ten-day period of December); the second (second ten-day period of March); third (third ten-day period of March); fourth (first ten-day period of April); Factor D - row spacing: $45 \mathrm{~cm} ; 70 \mathrm{~cm}$. The experiments were performed using field, laboratory, mathematical and statistical methods according to generally accepted in Ukraine methods and guidelines [Ushkarenko et al. 2014]. The experiment was based on the method of split sites. The surface area of the sown site was $105 \mathrm{~m}^{2}$, while the record site had a surface area of $50 \mathrm{~m}^{2}$. The experiment was repeated four times. Sowed variety of nutmeg sage, Taigan, is resistant to adverse abiotic environmental factors. Precursor crop - winter wheat, after harvesting of which stubble was buried in traces to a depth of 6-8 $\mathrm{cm}$. Mineral fertilizers were applied manually in the form of granular superphosphate and ammonium nitrate under the main tillage according to the experimental scheme. The moisture content of $0-50 \mathrm{~cm}$ soil layer was maintained with the drip irrigation method of at the level of $70-75 \% \mathrm{HB}$.

\section{RESULTS AND DISCUSSION}

To analyze the yield of nutmeg sage inflorescence depending on the studied factors, comparative indicators of crop productivity, which were obtained during the best first (winter) sowing period and the worst fourth (spring - first ten-day period of April) sowing period without fertilizers and when they were applied at a dose of $\mathrm{N}_{60} \mathrm{P}_{90}$, are provided.

The sowing time and the dose of fertilizers had greater impact on the productivity of sage than row spacing and ploughing depth. Namely, in the first three years of cultivation during winter sowing period the plants yielded 9.98-10.62 t/ha of inflorescences, while during the spring period $-4.87-5.11 \mathrm{t} / \mathrm{ha}$. With the use of mineral fertilizers at a dose of $\mathrm{N}_{60} \mathrm{P}_{90}$, the average yield during the years of cultivation was $7.77 \mathrm{t} / \mathrm{ha}$, which exceeded the control by $3.54 \mathrm{t} / \mathrm{ha}$ or $83.7 \%$.

The maximum productivity of the plant was achieved in the second year of cultivation during winter sowing period with row spacing of $45 \mathrm{~cm}$, 
Table 1. Yields of nutmeg sage inflorescence depending on the studied factors during the years of cultivation, $t /$ ha

\begin{tabular}{|c|c|c|c|c|c|c|c|}
\hline \multirow{4}{*}{$\begin{array}{l}\text { Sowing time } \\
\text { (factor C) }\end{array}$} & \multirow{4}{*}{$\begin{array}{l}\text { Row spacing, } \mathrm{cm} \\
\text { (factor D) }\end{array}$} & \multicolumn{4}{|c|}{ Fertilizer (factor A) } & \multirow{2}{*}{\multicolumn{2}{|c|}{ Average for facto }} \\
\hline & & \multicolumn{2}{|c|}{ No fertilizer } & \multicolumn{2}{|c|}{$\mathrm{N}_{60} \mathrm{P}_{90}$} & & \\
\hline & & \multicolumn{4}{|c|}{ Ploughing depth, cm (factor D) } & \multirow{2}{*}{$\mathrm{D}$} & \multirow{2}{*}{$\mathrm{C}$} \\
\hline & & $20-22$ & $28-30$ & $20-22$ & $28-30$ & & \\
\hline \multicolumn{8}{|c|}{ First year of cultivation, 2013-2015 } \\
\hline Winter & \multirow{2}{*}{45} & 5.82 & 6.36 & 14.61 & 14.51 & \multirow{2}{*}{7.60} & 10.33 \\
\hline Spring & & 3.93 & 5.48 & 4.60 & 5.48 & & 4.87 \\
\hline Winter & \multirow{2}{*}{70} & 5.81 & 6.52 & 14.74 & 13.62 & \multirow{2}{*}{7.61} & 10.17 \\
\hline Spring & & 4.50 & 4.72 & 5.52 & 5.46 & & 5.05 \\
\hline \multicolumn{8}{|c|}{ Second year of cultivation, 2014-2016 } \\
\hline Winter & \multirow{2}{*}{45} & 6.32 & 6.42 & 14.72 & 15.01 & \multirow{2}{*}{7.82} & 10.62 \\
\hline Spring & & 4.26 & 4.62 & 5.66 & 5.58 & & 5.03 \\
\hline Winter & \multirow{2}{*}{70} & 6.41 & 6.82 & 12.93 & 14.74 & \multirow{2}{*}{7.61} & 10.23 \\
\hline Spring & & 4.54 & 4.24 & 5.68 & 5.52 & & 5.00 \\
\hline \multicolumn{8}{|c|}{ Third year of cultivation, 2015-2017 } \\
\hline Winter & \multirow{2}{*}{45} & 6.01 & 6.38 & 14.02 & 14.61 & \multirow{2}{*}{7.57} & 10.26 \\
\hline Spring & & 4.02 & 4.56 & 5.46 & 5.48 & & 4.88 \\
\hline Winter & \multirow{2}{*}{70} & 6.00 & 6.38 & 12.93 & 14.61 & \multirow{2}{*}{7.54} & 9.98 \\
\hline Spring & & 4.54 & 4.58 & 5.68 & 5.62 & & 5.11 \\
\hline \multicolumn{8}{|c|}{ Fourth year of cultivation, 2016-2018 } \\
\hline Winter & \multirow{2}{*}{45} & 0.92 & 0.92 & 2.16 & 2.16 & \multirow{2}{*}{1.14} & 1.54 \\
\hline Spring & & 0.60 & 0.68 & 0.86 & 0.80 & & 0.74 \\
\hline Winter & 70 & 0.94 & 0.92 & 1.87 & 2.14 & \multirow{2}{*}{1.11} & 1.47 \\
\hline Spring & & 0.67 & 0.68 & 0.82 & 0.83 & & 0.75 \\
\hline \multicolumn{2}{|c|}{ Average for factor $B$} & 4.08 & 4.39 & 7.64 & 7.89 & & \\
\hline \multicolumn{2}{|c|}{ Average for factor $A$} & \multicolumn{2}{|c|}{4.23} & \multicolumn{4}{|c|}{7.77} \\
\hline & $D_{05} t / h a:$ for fact & $3, D-$ & 1 to 0.0 & r factor & .02 to 0. & & \\
\hline
\end{tabular}

ploughing depth of $28-30 \mathrm{~cm}$ and dose of $\mathrm{N}_{60} \mathrm{P}_{90}$ fertilizer of $15.01 \mathrm{t} / \mathrm{ha}$. With the same ploughing depth and dose of $\mathrm{N}_{60} \mathrm{P}_{90}$ fertilizer, high level of productivity, $14.74 \mathrm{t} / \mathrm{ha}$, was also achieved with row spacing of $70 \mathrm{~cm}$ (Table 1).

Regarding the duration of $S$. sclarea L. cultivation, it was determined that within the first three years, the inflorescence yield ranged from 9.98-10.62 $\mathrm{t} / \mathrm{ha}$, and in the fourth year-decreased by 6.8 times, amounting to $0.74-1.74 \mathrm{t} / \mathrm{ha}$. Such a sharp reduction in the inflorescence yield occurred due to the physiological aging of plants and their death, which were accompanied by a decrease in standing density, lower net productivity of photosynthesis and lower essential oil yield.

The analysis conducted at the beginning of spring vegetation and before winter showed a gradual decrease in standing density of plants both during the vegetation period of the year and in each consecutive cultivation year.

Thus, in spring of the first year of cultivation, the standing density of plants was in the range of $40-46$ units $/ \mathrm{m}^{2}$, with a maximum value when
$\mathrm{N}_{60} \mathrm{P}_{90}$ fertilizer was used. In winter, this figure was 39-45 units $/ \mathrm{m}^{2}$. In the second year of cultivation, the standing density in spring by was lower by $20.5 \%$, and in winter - by $27.5 \%$. In the third year of cultivation, the standing density was lower by $40.9 \%$ and $45.0 \%$ compared to spring and winter of the first year. In the fourth year of cultivation, the minimal indicators of plant density were recorded and were on average 5 units $/ \mathrm{m}^{2}$ in spring, which was $88.6 \%$ lower than in the first year, and 4 units $/ \mathrm{m}^{2}$ in winter, which was $90.0 \%$ lower than in the first year (Table 2).

Time of sowing and fertilizer doses, as well as the year of cultivation, had the greatest impact on the yield of sage essential oil. The maximum effect from the application of fertilizers in the dose of $\mathrm{N}_{60} \mathrm{P}_{90}$ was obtained during winter sowing period in the first two years of cultivation - the yield of essential oil increased 2.5 times compared to the control (without fertilizers). During spring sowing period, the yield was 1.4 times higher in the first year of cultivation and 1.7 times - in the second year (Fig. 2). 
Table 2. Standing density of $S$. sclarea L. plants depending on the studied factors during the years of cultivation, units $/ \mathrm{m}^{2}$

\begin{tabular}{|c|c|c|c|c|}
\hline \multirow{2}{*}{ Years of cultivation } & \multirow{2}{*}{ Ploughing depth, $\mathrm{cm}$} & \multirow{2}{*}{ Time of record of standing density } & \multicolumn{2}{|c|}{ Fertilizer (factor A) } \\
\hline & & & No fertilizer & $\mathrm{N}_{60} \mathrm{P}_{90}$ \\
\hline \multirow{4}{*}{$\begin{array}{c}\text { First } \\
2013-2015\end{array}$} & \multirow{2}{*}{$20-22$} & spring & 40 & 46 \\
\hline & & winter & 39 & 40 \\
\hline & \multirow{2}{*}{$28-30$} & spring & 45 & 46 \\
\hline & & winter & 39 & 45 \\
\hline \multirow{4}{*}{$\begin{array}{c}\text { Second } \\
2014-2016\end{array}$} & \multirow{2}{*}{$20-22$} & spring & 31 & 35 \\
\hline & & winter & 29 & 30 \\
\hline & \multirow{2}{*}{$28-30$} & spring & 34 & 38 \\
\hline & & winter & 24 & 33 \\
\hline \multirow{4}{*}{$\begin{array}{c}\text { Third } \\
\text { 2015-2017 }\end{array}$} & \multirow{2}{*}{$20-22$} & spring & 28 & 29 \\
\hline & & winter & 22 & 24 \\
\hline & \multirow{2}{*}{$28-30$} & spring & 23 & 25 \\
\hline & & winter & 21 & 22 \\
\hline \multirow{4}{*}{$\begin{array}{c}\text { Fourth } \\
2016-2018\end{array}$} & \multirow{2}{*}{$20-22$} & spring & 5 & 6 \\
\hline & & winter & 3 & 4 \\
\hline & \multirow{2}{*}{$28-30$} & spring & 4 & 5 \\
\hline & & winter & 3 & 4 \\
\hline
\end{tabular}

Application of mineral fertilizers at doses similar to $\mathrm{N}_{60} \mathrm{P}_{90}$ under the main tillage during winter sowing period resulted in $51.1 \mathrm{~kg} / \mathrm{ha}$ and $51.3 \mathrm{~kg} / \mathrm{ha}$ yields of essential oil in the first and second years of cultivation, respectively. In the third and fourth years, the yields dropped to $33.3 \mathrm{~kg} / \mathrm{ha}$ and $8.7 \mathrm{~kg} / \mathrm{ha}$ or by $35.1 \%$ and $83.0 \%$, respectively. During the spring sowing period, the yield of essential oil was in the range of $19.2-24.6 \mathrm{~kg} / \mathrm{ha}$ in the first three years, but in the fourth year - decreased to $6.5 \mathrm{~kg} / \mathrm{ha}$ or by $73.6 \%$.

\section{CONCLUSIONS}

To obtain an inflorescence yield of nutmeg sage at the level of 14.5-15.0 $\mathrm{t} / \mathrm{ha}$ with essential oil yield of $51.0 \mathrm{~kg} / \mathrm{ha}$ in arid climates, it is recommended to use the following conditions: row spacing of $45 \mathrm{~cm}$, ploughing depth of $28-30 \mathrm{~cm}$, fertilizer at a dose of $\mathrm{N}_{60} \mathrm{P}_{90}$ and sowing time in the first ten-day period of December (winter period). In dry years, drip irrigation should be used to maintain the optimal level of soil moisture in the root layer. Regarding the duration of S. sclarea L.

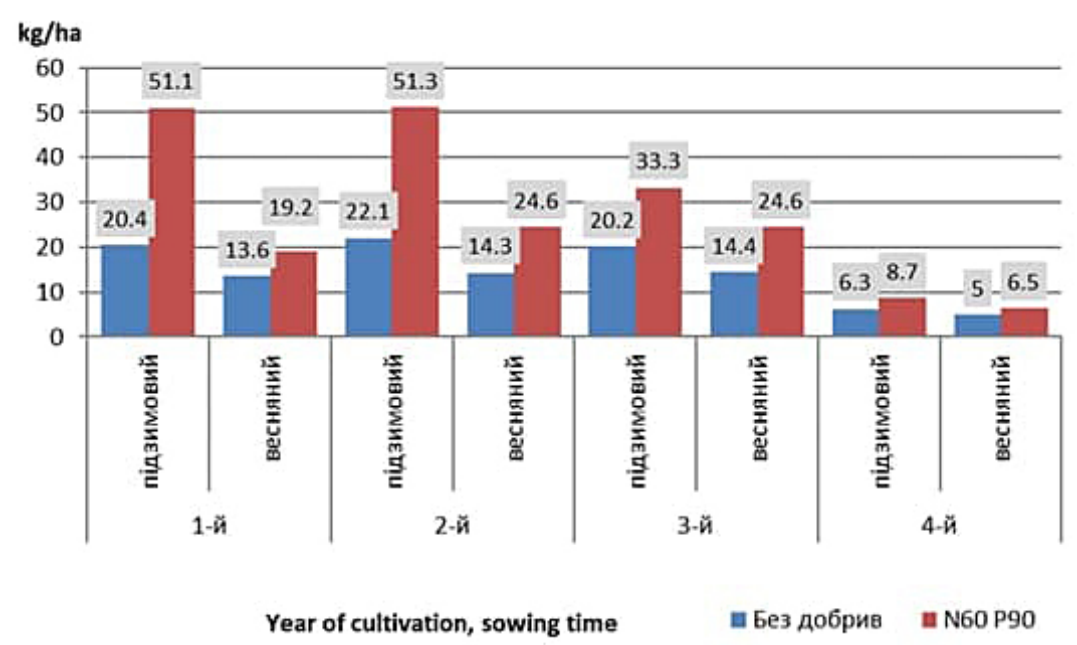

Figure 2. Yield of nutmeg sage essential oil depending on the sowing time and fertilizer doses, $\mathrm{kg} / \mathrm{ha}$ (average for 2013-2018) 
cultivation, it was determined that within the first three years the inflorescence yield ranged from 9.98-10.62 t/ha, and in the fourth year - decreased by 6.8 times, amounting to $0.74-1.74 \mathrm{t} / \mathrm{ha}$. The optimal cultivation period of $S$. sclarea L. crops is three years.

\section{REFERENCES}

1. Chaban V.O., Ushkarenko V.O. 2020. Scientific substantiation of growing sage in conditions of drip irrigation of the Southern Steppe of Ukraine: monograph. Kherson. (in Ukrainian)

2. Dudchenko V., Svydenko L., Markovska O., Sydiakina O. 2020. Morphobiological and biochemical characteristics of Monarda L. varieties under conditions of the Southern Steppe of Ukraine. Journal of Ecological Engineering, 21(8), 99-107. DOI: 10.12911/22998993/127093 (in Ukrainian)

3. Dzumayev K. K., Tsibulskaya I. A., Zenkevich I. G., Tkachenko K. G., Satzyperova I. F. 1995. Essential oils of Salvia sclarea L. produced from plants grown in Southern Uzbekistan. Journal of essential oil research, 7(6), 597-604.

4. Farka P., Hollá M., Tekel J., Mellen S., Vaverková T. 2005. Composition of the essential oils from the flowers and leaves of Salvia sclarea L.(Lamiaceae) cultivated in Slovak Republic. Journal of Essential Oil Research, 17(2), 141-44.

5. Grigoriadou K., Trikka F. A., Tsoktouridis G., Krigas N., Sarropoulou V., Papanastasi K., Maloupa E., Makris A. M. 2020. Micropropagation and cultivation of Salvia sclarea for essential for oil and sclareol production in northern Greece. In Vitro Cellular \& Developmental Biology-Plant, 56, 51-59. DOI: $10.1007 / \mathrm{s} 11627-019-10040-4$

6. Makukha O., Markovska O., Mynkina H., Chernyshova Y. 2018. The impact of seeding dates and depth on the productivity of Common Fennel (Foeniculum vulgare Mill.) under the conditions of the Southern Steppe of Ukraine. Research Journal of Pharmaceutical, Biological and Chemical Sciences, 9 (6), 1075-1083

7. Mamadalieva N.Z., Akramov D.K., Ovidi E., Tiezzi A., Nahar L., Azimova S.S., Sarker, S.D. 2017. Aromatic medicinal plants of the Lamiaceae family from Uzbekistan: ethnopharmacology, essential oils composition, and biological activities. Medicines, 4(1), 8. DOI: 10.3390/medicines4010008

8. Markovska O, Svydenko L., Stetsenko I. 2020. Comparative assessment of morphometric features and agronomic characteristics of lavandula angustifolia Mill. and lavandula hybrida Rev. Scientific Horizons, 2(87), 24-31. DOI: 10.33249/26632144-2020-87-02-24-31 (in Ukrainian)
9. Mirzoeva T. 2019. Economic aspects of manufacture of medicinal plants from which are essential oils. Economics and management of the national economy, 3(71), 79-84. DOI: 10.32782/2520-2200/2019-312 (in Ukrainian)

10. Mirzoeva T. 2019. Some aspects of formation of strategy of development of medicinal plant growing. Medicinal plants: traditions and research prospects: materials of the IV International scientific conference, 160-164. (in Ukrainian)

11. Nasermoadeli S., Rowshan V. 2013. Comparison of Salvia sclarea L. essential oil components in wild and field population. International Journal of Agriculture and Crop Sciences, 5(8), 828-831.

12. Olkhovich S., Fedko L. 2019. Market prospects of agricultural enterprises focused on the production of non-traditional crops. Medicinal plants: traditions and prospects of research: materials of the IV International scientific conference, 164-168. (in Ukrainian)

13. Rabotyagov V.D., Svydenko L.V., Derevyanko V.N., Boyko M.F. 2003. Essential oil and medicinal plants introduced in the Kherson region (ecological and biological features and economically valuable traits). Aylant, Kherson. (in Ukrainian)

14. Rabotyagov V.D., Khlypenko L.A., Svydenko L.V., Logvinenko I.Ye. 2011. New varieties of aromatic and medicinal plants bred by Nikitsky Botanical Garden. Proceedings of the state. Nikitsky bot. garden, 133, 5-7. (in Ukrainian)

15. Sharopov Farukh S., Setzer William N. 2012. The essential oil of Salvia sclarea L. from Tajikistan. Records of natural products 6 (1), 75-79.

16. Svydenko L.V., Yezhov V.M. 2015. Perspectives for cultivation of some essential oil crops in the Steppe South. Bulletin of Agricultural Science, 6, 20-24. (in Ukrainian)

17. Tibaldi G., Fontana E., Nicola S. 2010. Cultivation practices do not change the Salvia sclarea L. essential oil but drying process does. Journal of Food, Agriculture \& Environment, 8 (3\&4), 790-794.

18. Tuttolomondo T., Iapichino G., Licata M., Virga G., Leto C., La Bella S. 2020. Agronomic evaluation and chemical characterization of Sicilian Salvia sclarea L. accessions. Agronomy, 10(8), 1114. DOI: 10.3390/agronomy10081114

19. Ushkarenko V.O., Kokovikhin S.V., Holoborodko S.P., Vozhehova R.A. 2014. Methods of field experiment (Irrigated farming). Hrin DS, Kherson. (in Ukrainian)

20. Yurchak L.D., Pobirchenk G.A. 1997. National Botanical Garden named after M.M. Grishka of the National Academy of Sciences of Ukraine, Nauk. Dumka, Kyiv. (in Ukrainian) 